\title{
RAPD analysis for genetic diversity of germplasm resources of Strobilanthes
}

\author{
Shuju Ning ${ }^{\#}$, Yingjiao Zhang ${ }^{\#}$, Renlei Zhu, Lanfang Zhu, Jianyong Lin, Daozhi Wei ${ }^{\dagger}$ \\ School of Life Sciences, Fujian Agriculture and Forestry University, Fuzhou, China; \\ ${ }^{\dagger}$ Corresponding Author: weidz888@sohu.com
}

Received 11 January 2012; revised 19 February 2012; accepted 5 March 2012

\begin{abstract}
The 18 samples representing 18 populations of Strobilanthes cusia (Nees) 0 . Ktze in Fujian Province of China were analyzed with RAPD markers. Eleven primers were used, a total of 106 bands were scored and 88 of them were polymorphic. The percentage of polymorphic loci was $77.36 \%$, Nei's gene diversity was 0.2420 , and Shannon's index was 0.3700 . The 18 populations were classified into 2 groups based on the RAPD data by the method of hierarchical cluster analysis. Most of the populations from Fujian were clustered into a group, other populations were clustered into the other group. There was a high level of genetic diversity among the populations, and the genetic differentiation was obvious among the populations from Fujian.
\end{abstract}

Keywords: Strobilanthes cusia (Nees) O. Ktze; RAPD; Germplasm Resources; Genetic Diversity

\section{INTRODUCTION}

Strobilanthes cusia (Nees) (O. Ktze) belong to Acanthaceae. It is distributed in southern China, including Zhejiang, Fujian, Hunan, Guangxi, Guangdong, Sichuan, Guizhou, Yunnan etc. [1]. It is an original plant of Indigo, an Chinese medicine product. The indigo produced in Fujian has the best quality, and famous for "jian indigo" [2]. Therefore, Fujian is the origin place of this famous local drug.

There is a long history of cultivation and rich wild resources of Strobilanthes cusia (Nees) O. Ktze in Fujian. However, as the destruction of natural environment, the distribution area of wild resources has decreased, whereas

\footnotetext{
*This work was supported by the Natural Science Foundation of Fujian Province (2011J01074), the Foundation of ecology key discipline of Fujian Province (0608537).

\#These authors have equal contribution to the study.
}

the market demand for Strobilanthes cusia (Nees) O. Ktze has significantly increased with the increase in drug application of Indigo. No studies on the resources of Strobilanthes cusia (Nees) O. Ktze in Fujian has been reported.It is important to develop the artificial cultivation and strengthen the investigation, collection and protection of wild species resources of Strobilanthes cusia (Nees) O. Ktze. Although some morphological characters of the Strobilanthes cusia (Nees) O. Ktze vary greatly, they are easily affected by environmental factors. Hence, comparison only based on the morphological characters will not be able to reveal the diversity of germplasm resources of Strobilanthes cusia (Nees) O. Ktze effectively and scientifically. Using molecular markers to analyze genetic diversity, genetic characteristics and genetic relationship among different germplasms will provide theoretical foundation for the introduction, resource protection and breeding of Strobilanthes cusia (Nees) O. Ktze.

\section{MATERALS AND METHODS}

\subsection{Plant Materals}

Eighteen samples each representing an individual population of Strobilanthes cusia (Nees) O. Ktze (Table 1) were collected from 25 sampling locations in 21 counties of Fujian and some other nearby provinces. The samples were identified by professor Wei Dao-zhi and preserved in the herbarium of Fujian Agriculture and Forestry University.

\subsection{DNA Extraction}

The CTAB method [3] was used to extract total DNA. Fresh leaves should be used because Strobilanthes cusia (Nees) O. Ktze are rich of phenols and other secondary metabolites including indigo, which can be oxidized and bound with DNA easily so as to affect DNA extraction.

\subsection{Selection of Primers}

Eleven primers that could yield clear, stable and reliable PCR products with abundant polymorphisms were 
Table 1. The collecting locations of Strobilanthes cusia (Nees) O. Ktze samples.

\begin{tabular}{|c|c|}
\hline $\begin{array}{l}\text { Sample } \\
\text { Number }\end{array}$ & collecting location \\
\hline QY & QingYun maintain, Yongtai county, Fujian province \\
\hline $\mathrm{CB}$ & Chibi, Yongtai county, Fujian province \\
\hline $\mathrm{XL}$ & $\begin{array}{l}\text { Zijin maintain, Xinluo district, Longyan city, Fujian } \\
\text { province }\end{array}$ \\
\hline $\mathrm{ZP}$ & $\begin{array}{l}\text { Shimen village, Pingguan town, Zhangpingcounty, } \\
\text { Longyan city, Fujian province }\end{array}$ \\
\hline $\mathrm{XK}$ & $\begin{array}{l}\text { Forestry station, Gulai village, Xianyou county, Fujian } \\
\text { province }\end{array}$ \\
\hline SF & Shufeng town, Xianyou county, Fujian province \\
\hline BT & $\begin{array}{l}\text { Wudun village, Bongtou town, Xianyou county, } \\
\text { Fujian Province }\end{array}$ \\
\hline LT & Letu rainforest, Nanjin county, Fujiang Province \\
\hline $\mathrm{CC}$ & $\begin{array}{l}\text { Xia maintain village, Chuanchang town, Nanjin county, } \\
\text { Fujian Province }\end{array}$ \\
\hline NP & $\begin{array}{l}\text { Mangdang maintain natural reserve, Nanping city, Fujian } \\
\text { Province }\end{array}$ \\
\hline MH & Flag maintain, Minhou county, Fujian Province \\
\hline SL & Forest park, Fuzhou, Fujian Province \\
\hline ZQ & Dinghu maintain, Zhaoqing, Guangdong Province \\
\hline GZ & Guangzhou city, Guangdong Province \\
\hline $\mathrm{CZ}$ & Tiandeng county, Congzuo city, Guangxi Province \\
\hline $\mathrm{NN}$ & Nanning city, Guangxi Province \\
\hline GY & Guiyang city, Guizhou \\
\hline $\mathrm{SC}$ & Yibin city, Sichuan \\
\hline
\end{tabular}

selected from 100 random primers (Sangon products; Table 2).

\subsection{PCR Amplification and Detection of the Products}

The PCR amplification was carried out in MyCycler PCR. The reaction system volume was $20 \mu \mathrm{L}$, containing $10 \times$ PCR buffer $2.0 \mu \mathrm{L}$, dNTP mixture (each 2.5 $\left.\mathrm{mmol} \cdot \mathrm{L}^{-1}\right) 2.4 \mu \mathrm{L}, 20 \mathrm{mmol} \cdot \mathrm{L}^{-1}$ primers $0.4 \mu \mathrm{L}, \mathrm{Mg}^{2+}$ $0.4 \mu \mathrm{L}$ DNA template $2 \mu \mathrm{L}\left(10 \mathrm{ng} \cdot \mu \mathrm{L}^{-1}\right)$ and Taq $(5$ $\left.\mathrm{U} \cdot \mu \mathrm{L}^{-1}\right) 0.2 \mu \mathrm{L}$, DDW $12.6 \mu \mathrm{L}$. The PCR program was: fore- denaturalization at $95^{\circ} \mathrm{C}$ for $5 \mathrm{~min} ; 38$ cycles of degeneration at $94^{\circ} \mathrm{C}$ for $45 \mathrm{~s}$, renaturation at $38^{\circ} \mathrm{C}$ for $1 \mathrm{~min}$, extension at $72^{\circ} \mathrm{C}$ for $2 \mathrm{~min}$; and final extension at $72^{\circ} \mathrm{C}$ for $5 \mathrm{~min}$. The PCR products were separated by electrophoresis on $1.5 \%$ agarose gel and visualized by ultraviolet.
Table 2. Primers selected for the experiment.

\begin{tabular}{cccc}
\hline Primer & Sequence & Primer & Sequence \\
\hline S2 & TGATCCCTGG & S174 & TGACGGCGGT \\
S5 & TGCGCCCTTC & S364 & CCGCCCAAAC \\
S7 & GGTGACGCAG & S367 & AGCGAGCAAG \\
S64 & CCGCATCTAC & S368 & GAACACTGGG \\
S65 & GATGACCGCC & S369 & CCCTACCGAC \\
S67 & GTCCCGACGA & & \\
\hline
\end{tabular}

\subsection{Recording and Analysis of the Datas}

PCR bands were recorded as 1 for presence and 0 for absence. The computer program POPGENE32 was used to analyze the genetic parameters of the populations, calculating percentage polymorphic bands (PPB), number of alleles per locus (Ao), effective number of alleles per locus (Ae), Nei's gene diversity (H), Shannon's information index (I), Nei's genetic identity $(J)$, genetic distance (D). Cluster analysis was performed using the UPGMA method. The phylogenetic tree among the samples was established by calculating the continental distance with SPSS 13.0 analysis software. The between groups linkage method was applied to the cluster analysis.

\section{RESULTS}

\subsection{Genetic Diversity of Strobilanthes cusia (Nees) O. Ktze}

The PCR analysis on the 18 DNA samples of Strobilanthes cusia (Nees) O. Ktze with 11 primers detected 106 bands ranging $200-3000$ bp (Figures 1 and 2), of which 88 were polymorphic. Based on these data, it could be calculated that the $\mathrm{PPB}=77.36 \%, \mathrm{AO}=1.7736$, $\mathrm{Ae}=1.4025, \mathrm{H}=0.2420$, and $\mathrm{I}=0.3700$. Among the 12 samples from Fujian, the PPB $=72.28 \%$, Ao $=1.7228$, $\mathrm{Ae}=1.4060, \mathrm{H}=0.241, \mathrm{I}=0.3654$. These results indicated that abundant genetic diversity existed among different Strobilanthes cusia (Nees) O. Ktze populations.

\subsection{Genetic Similarity and Genetic Distances between Strobilanthes cusia (Nees) O. Ktze. Populations}

The genetic distances and genetic similarity between the Strobilanthes cusia (Nees) O. Ktze populations were calculated according to the Nei method (Table 3). The results indicated that the genetic similarity between 18 populations was in range of $0.6321-0.8868$. The populations of GY and BT had the maximum genetic similarity between them, while QY and CZ had the minimum. In contrast, the genetic distance between $\mathrm{QY}$ and $\mathrm{CZ}$ was 


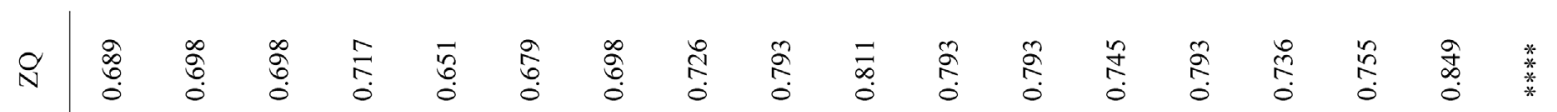

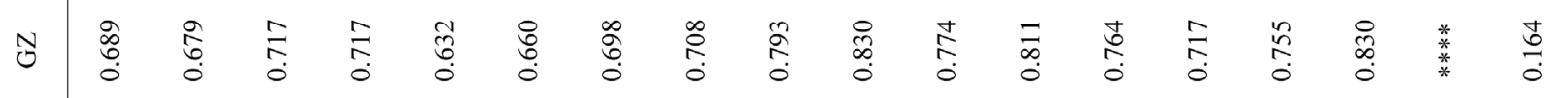

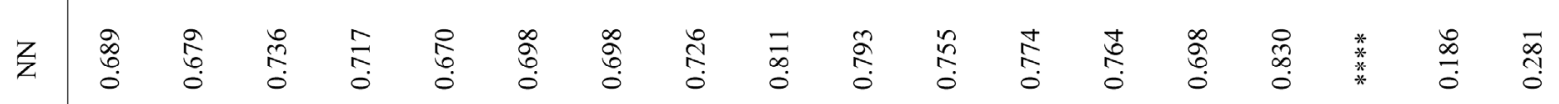

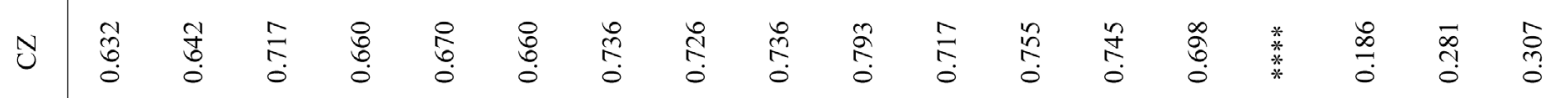

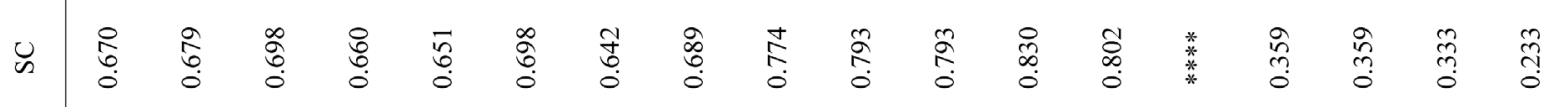

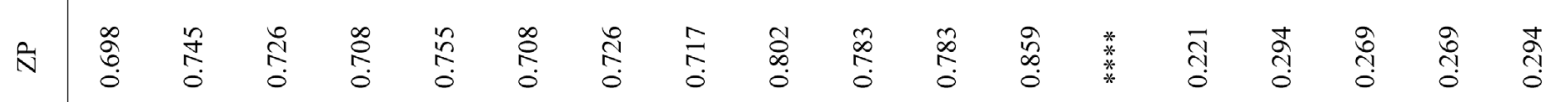

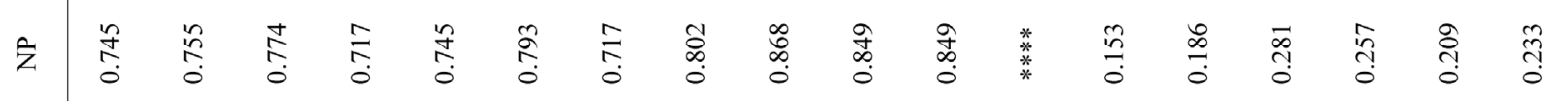

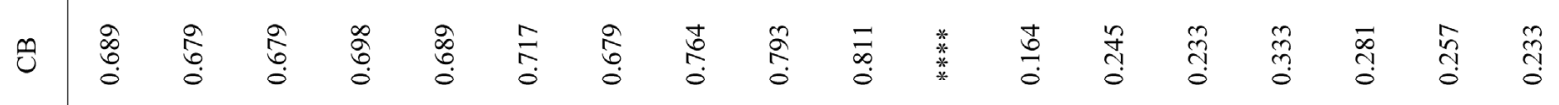

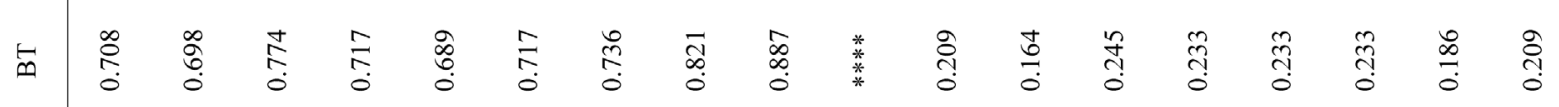

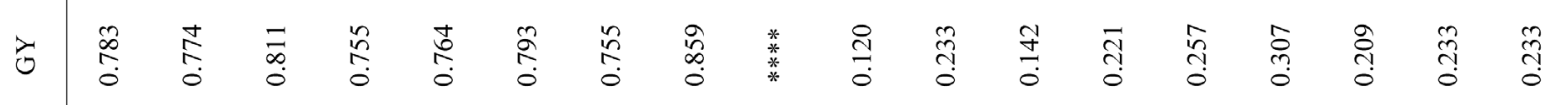

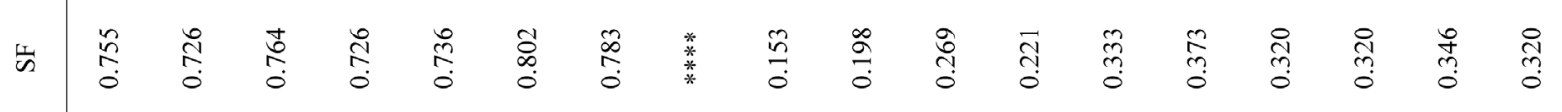

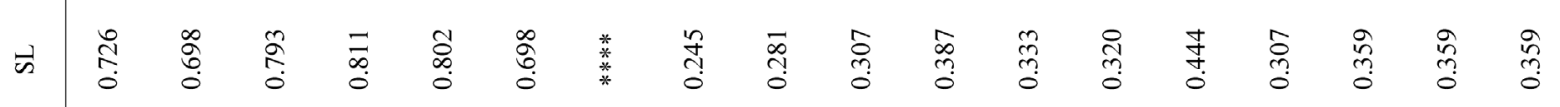

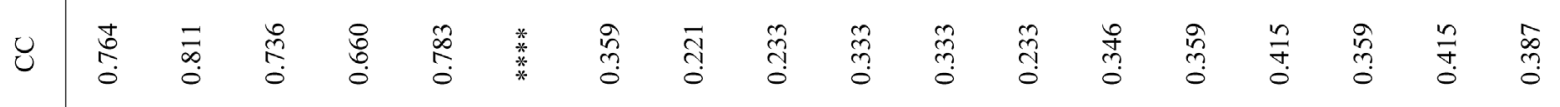

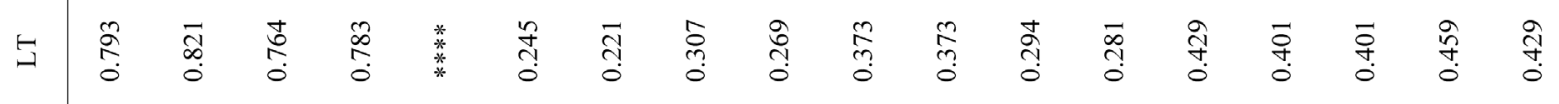

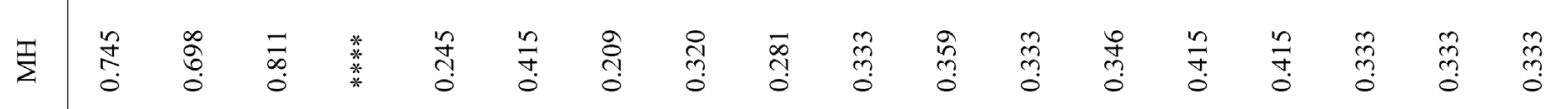

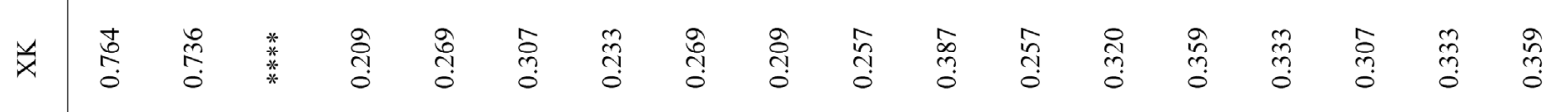

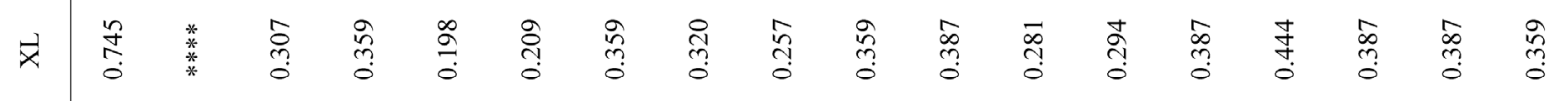

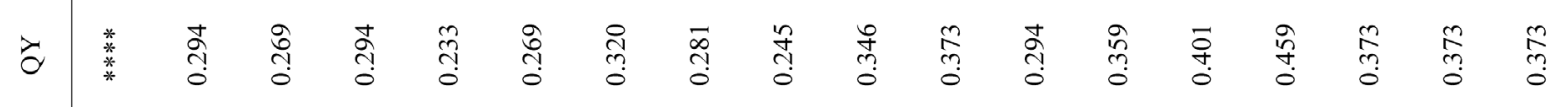

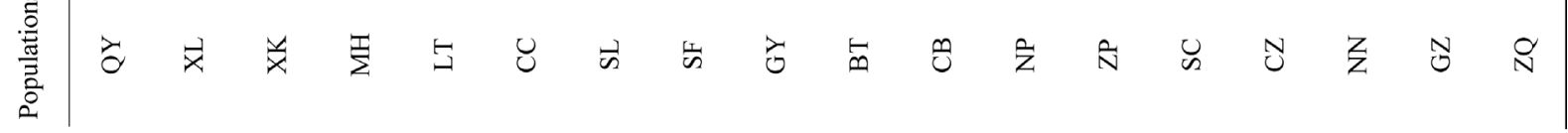


the maximum (0.4587), while that between GY and BT was the minimum (0.1201). These results suggest that there is sufficient genetic differentiation among the Strobilanthes cusia (Nees) O. Ktze's populations.

\subsection{Cluster Analysis}

The clustering analysis (Figure 3) also showed that BT and GY had the highest similarity and were classified into a group earliest. In addition, ZP was quite similar to $\mathrm{NP}$ and they were classified into a group.

GZ and ZQ had a higher similarity and were classified into a group. $\mathrm{CZ}$ and $\mathrm{NN}$ were in group $\mathrm{b}$. The 12 populations from Fujian could be classified into five classes, SF and BT were grouped as class A, both of which belong to Xianyou's populations and have near geographical locations. ZP, NP and CB were grouped into class B.

$\mathrm{XK}, \mathrm{MH}$ and SL were grouped as class $\mathrm{C}$. They are all located in Fujian and have near geographic positions. LT, $\mathrm{CC}$ and XL were classified as class D. They are all located near geographically in the south area of Fujian province. QY was classified as a class E itself.

The above results indicate that the differentiation among populations is obvious, though the sampling was intensive from Fujian province. In addition, GY and SC were grouped into class A and B respectively. Finally, Class C, D and E of Fujian are grouped into class I; other small classes were grouped into class II. There were two major categories for all the samples.

It can be seen from the phylogenetic tree that most of the populations were classified into groups in consistency with their geographical locations, such as classes B, $\mathrm{C}$ and D from Fujian province. However, inconsistency

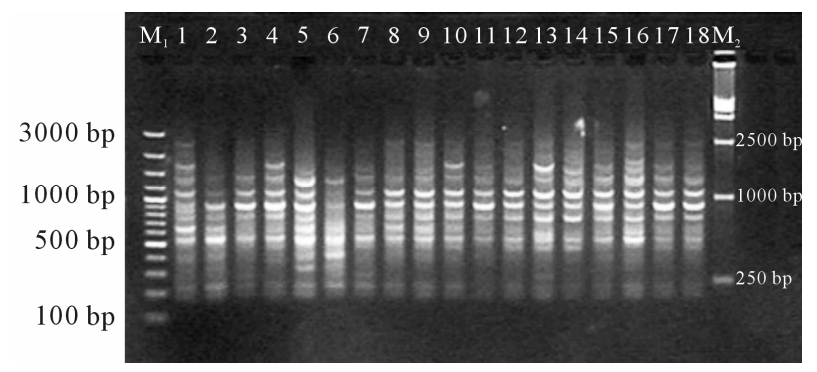

Figure 1. PCR results of primer S56.

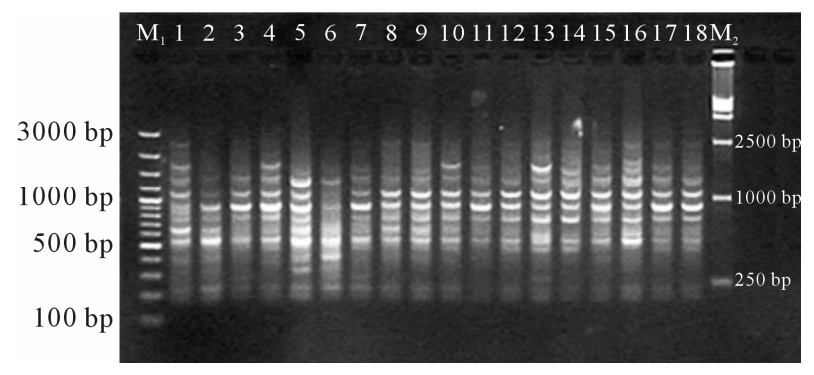

Figure 2. PCR results of primer S3677.

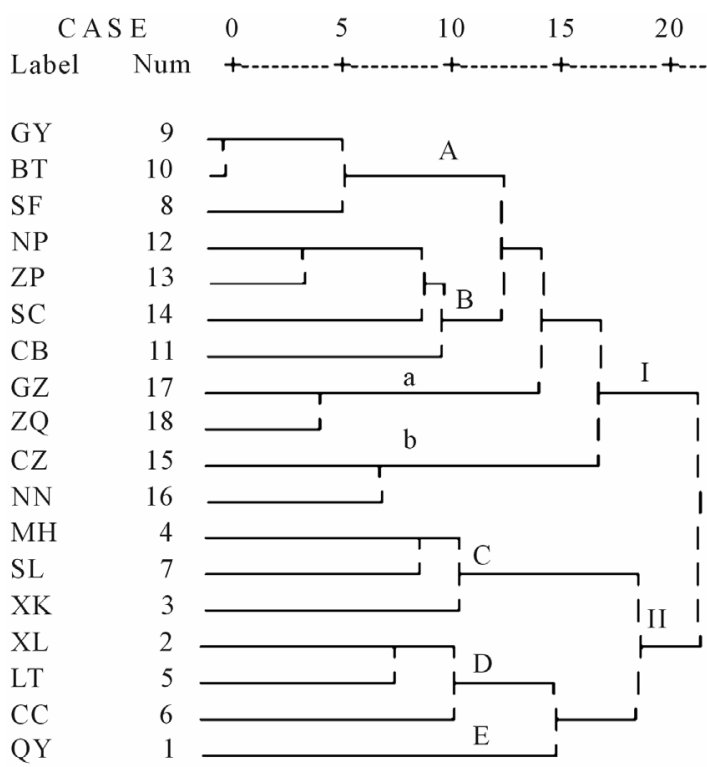

Figure 3. Phylogenetic tree of the populations.

also existed between the genetic distance and the geographical distance. For example, among the three populations from Xianyou (XM, SF, BT), only two were grouped into a class, suggesting that there might be two species in that production place. Although Guizhou and Sichuan are geographically far from Fujian, the populations from them were classified into the same class with those from Fujian, respectively. It was explained that geographical locations and environmental factors are very important for the formation of resources class. Although they are from different locations, their own genetic characteristics are relatively stable.

\section{DISCUSSION}

Strobilanthes cusia (Nees) O. Ktze contains a lot of carbohydrates, phenols and other secondary metabolites. These substances can severely disturb DNA extraction.

The indigo is rich in Strobilanthes cusia (Nees) O. Ktze's leaves. It is vulnerable to oxidation, and can bind with DNA easily, resulting in the damage of DNA. Leaves may become black when indigo is oxidized, which would lead to DNA contraction, looking yellow or light brown. Therefore, the leaves used for DNA extraction should be fresh and saved in liquid nitrogen rapidly.

The geographical location and environmental factors are important external factors that make resources heterogeneous. This is morphologically obvious among different populations and between wild and cultivated species. However, some populations with far genetic distances exhibit little morphological difference. Hence, morphological traits are not accurate indicators for determining the genetic relationships among different populations of Strobilanthes cusia (Nees) O. Ktze. In- 
stead, molecular markers can reveal the genetic relationships among accessions more effectively and accurately.

The results of this study indicate that Strobilanthes cusia (Nees) O. Ktze has a strong adaptive capacity to environment and thus exhibits high genetic diversity. The natural populations of Strobilanthes cusia (Nees) O. Ktzere in Fujian are concentrated in Fuzhou, Putian and Zhangzhou. These districts are abundant of wild communities that are large and grow well. They were important germplasm resources for breeding. In recent years, along with the deterioration of their habitat environment and increasing collection in disorder, the wild germplasm resources of Strobilanthes cusia (Nees) O. Ktze are decreasing seriously. Therefore, protection of the genetic resources of Strobilanthes cusia (Nees) O. Ktze in Fujian has become urgent.

\section{ACKNOWLEDGEMENTS}

Thank Professor Wei-ren Wu for revising this paper.

\section{REFERENCES}

[1] Anonym (1975) A collection of the medicine Heber in China. Beijing People's Medical Publishing House, Beijing.

[2] Qian, Y.C. (1999) Investigation of the Strobilanthes cusia (Nees) O. Ktzehas in south Zhejiang province. Lishizhen Medicine and Materia Medica Research, 10, 7-8.

[3] Ausubel, F.M., Brent, R., Kingston, R.E., Moore, D.D., Seidman, J.G., Smith, J.A. and Struhl, K. (2002) Short protocols in molecular biology. 5th Edition, Wiley, New York. 